\title{
Zakat Assessment for Agricultural in Malaysia: Rules, Fatawa, and Practices
}

\author{
Zahri Hamat \\ Centre for Islamic Development Management Studies (ISDEV) \\ School of Social Sciences, Universiti Sains Malaysia \\ 11800 Minden, Pulau Pinang \\ E-mail: zahri@usm.my
}

\section{Doi:10.5901/jesr.2014.v4n2p110}

\section{Abstract}

This paper aims to analyze the assessment of agricultural zakat among farmers in Malaysia based on manuals, fatawa and practices of various zakat institutions in Malaysia. According to the rules the assessment of agricultural zakat is made after deducting the production costs or farming cost. However, the fatawa issued by most of the states in Malaysia does not allow the farming costs such as fertilizers, plowing seeds, harvesting and transportation to be deducted, let alone, the living costs of the farmers. Nevertheless, the zakat assessment for income shows otherwise, where one's living costs are allowed to be deducted from one's gross income. Based on content analysis on secondary data as well as primary data, the discussions in this paper are divided into three sections. Firstly, this paper reviews in brief the classical works on production costs and living costs as the background of this research. Secondly, this paper examines the present zakat assessment method for agriculture as practiced by the zakat institutions in Malaysia. Thirdly, this paper intends to analyze the agricultural zakat assessments that ought to be practiced, by taking into account the classical works and types of agricultural zakat of today. It is therefore important to note that, by taking into consideration the type of agriculture nowadays, there is a strong and urgent need for a reevaluation of the agricultural zakat assessment. In addition, the meaning of zakat itself is taking the assets from the rich to be distributed to the poor and not otherwise.

Keyword: zakat assessment, fatawa, production cost, living cost

\section{Introduction}

In Malaysia, agricultural produce or crops that are subject to zakat assessment can be divided into two categories. Firstly, crops which are consumed as staple food and secondly, crops which are cultivated commercially. Crops which are consumed as staple food are subject to agricultural zakat assessment, while, those cultivated commercially are subject to zakat for business income.

Rules for assessment of zakat for both agricultural incomes are described in Manual Pengurusan Pengiraan Zakat. This manual serves as a reference in determining the standardized assessment of zakat in Malaysia (JAWHAR, 2008). According to the manual, the assessment of agricultural zakat is made after deducting the production costs or farming costs, which include cost of plowing, fertilizing, pesticides and harvesting.

In contrast, the fatawa issued by most of the states in Malaysia does not allow the production costs to be deducted, let alone, the cost of living of the farmers. On the other hand, the zakat assessment for income allows the deduction of one's living cost from one's gross income. As such, the differences in the assessment do trigger some important questions such as, why there are differences in the zakat assessment for agricultural produce and assessment on employment and why this was the case? What are the reasons for not allowing the deduction of production costs in the zakat assessment, especially crops cultivated commercially? Is it because for crops that are cultivated commercially, the reasonable assessment of agricultural zakat does not allow the deduction of production costs?

Based on content analysis on secondary data as well as primary data, the discussions in this paper are divided into three sections. First, this paper reviews briefly classical works on production costs and living cost as the background. Second, this paper examines the present zakat assessment methods for agricultural produce as practiced by the zakat institutions in Malaysia. Third, this paper intends to analyze the agricultural zakat assessments that ought to be practiced by taking into account the classical works and types of agricultural zakat of today. 


\section{Cost of Living and Production Costs}

In the Holy Qur'an, it was mentioned in general, that zakat is compulsory on agricultural income. Among others is Allah said, "Eat of their fruit when they ripen, but pay the due thereof on the day of their harvest" (al-An'am, 6: 141). According to Ibn Kathir (2001: 239), Muhammad b. Ka'b said that eat from the dates and grapes they produce, Allah said next, but pay the due thereof on the day of their harvest. Mujahid also commented, when the poor people are present (on the day of harvest), give them some of the produce. The method of zakat assessment on agricultural produce is assessed based on the surplus and more than the needs. Allah mentioned in the Holy Quran:

"And they ask you what they ought to spend (infaq). Say: That which is (spare) beyond your needs" (al-Baqarah, 2: 219).

In addition, Ibn Kathir (1993: 132) mentioned, "and they ask you what they ought to spend", Ibn Abbas said that this ayah means, whatever you can spare above the needs of your family. This is also the opinion of Ibn Úmar, Mujahid, Ata, Ikrimah, Sa ì b. Jubayr, Muhammad b. Ka`b, Al-Hasan, Qatadah, Al-Qasim, Salim, Ata Al-Khurasani and Ar-Rabi b. Anas. Muslim reported from Jabir, Allah's Messenger said to a man as follows:

"Start with yourself and grant it some charity. If anything remains, then spend it on your family. If anything remains, then spend it on your relatives. If anything remains, then spend it like this and like that (i.e., on various charitable purposes)" (Ibn Kathir, 2001: 133).

In classical literature, the cost of living is debated with reference to the debt issues. Among others is Abu Úbayd (2006) in kitab al-Anwal. For instance, Abu Úbayd reported from Ibrahim b. Sa'd, from Ibn Shibab, from Ibn Said AlYazid, the Caliph Úthman b. 'Affan said as follows:

"This is the month of zakat. Whoever is indebted, he should first pay his debt, so that he may be able to pay his zakat (if due). Whoever has not (zakat-able) possession, no zakat will be taken from him. However, he can do so voluntarily. Who will pay his zakat nothing will be taken from him in the next year before the start of this month. Ibrahim: here by month means the month of Ramadan (in which zakat is paid)" (Abu Úbayd, 2006: 372).

Abu Úbayd (2006) has discussed this Hadith in detail, focusing on two main issues, which are cost of plantation and cost of living. With reference to these costs, Abu Úbayd reported from Jabir Ibn Zayd said as follows:

"Ibn 'Abbas concerning a person, who spends the amount the amount loaned on his family or land, said that he would pay the loan taken for land (i.e, he would deduct it from zakat). Ibn Úmar concerning such person said that he would pay the loan spent on himself or his family" (Abu Úbayd, 2006: 424).

Abu Úbayd (2006) argued that the cost of production and cost of living can be fully deducted from the gross agricultural produce. Similar views were shared by Ibn Úmar and Ibn Abbas where the cost of plantation is deductible from the gross income. Based on the argument by Abu Úbayd (2006) it can be concluded that farming costs and living costs are allowed to be deducted from the gross income. This was due to the fact that Ibn Úmar allow the deduction of living costs while Ibn' Abbas allows the deduction of farming costs. Actually, Abu Úbayd holds the view of Ibn Úmar which can be traced from the conclusions made by Abu Úbayd as follows:

"If it is known that the owner of the land is actually indebted, the zakat will not be taken from his produce of land, and it will be exempted from him because of his loan. This is according to the opinion of Ibn Úmar, Ta'us, 'Ata and Makhul. This is in according with the Sunnah also because the Prophet (peace be upon him) has prescribed that zakat will be taken from the rich and distributed among the poor. How can zakat be collected from a person is indebted equal to his possession, i.e. he has no possession and is entitled to receive zakat? How is it possible that he may be rich as well as poor at same time? Moreover, he (the indebted person) is one of the beneficiaries of zakat (i.e. Gharim) and is entitled to receive zakat in two capacities (i.e. being poor an indebted) (Abu Úbayd, 2006: 425).

According to Abu Úbayd (2006) zakat is to be taken from the rich and distributed among the poor. In addition, question trigger on how zakat is collected from a person who is indebted? Is it possible that the person may be rich as well as poor at same time? Abu Úbayd (2006) further argued that indebted person is one of the beneficiaries of zakat and is entitled to receive zakat in two capacities (i.e. being poor and indebted). Additionally, it was also the views from Iraqi's 
Islamic scholars who hold the opinion of Ibn Úmar, Tawus, Áta and Makhul (Abu Úbayd, 2006: 424).

As mentioned by Yusuf al-Qaradawi (1999), Ibn 'Abbas views debts spent on the land must be paid back first, but views from Ibn Úmar is both debts on farming and family must be deducted. Both of them agreed that debts on farming are deductible, but both disagree on deducting debts for family and personal use. He concluded that the decision made by Prophet varies according to the difference in effort expended in irrigating the land. ${ }^{1}$

\section{Agricultural Zakat Assessment in Malaysia: Rules and Fatawa}

The method of agricultural zakat assessment was described in Manual Pengurusan Pengiraan Zakat published by Jabatan Wakaf, Zakat dan Haji (JAWHAR) in 2008. Minister in the Prime Minister Department, Dr. Ahmad Zahid Hamidi expressed his hope that the manual will served as a guide to all the states in Malaysia. He expressed his hope as follows:-

"I very much hope that this Manual Pengurusan Pengiraan Zakat adopted and used as a guide by all the State Islamic Religious Council in zakat assessment. Any rules or procedures will be more beneficial if it is practiced regularly, rather than just arrange it nicely in the book" (JAWHAR, 2008, ii).

In addition, he further stressed that with the application of the manual,the standardization and coordination of the zakat assessment could be realized (JAWHAR, 2008). Zakat on agricultural can be further categorized into two parts. First, is the consensus (ittifaq) zakat on agriculture, which is paddy and second, the disensus zakat such as rubber and plam oil. Paddy is subject to agricultural zakat assessment evethough it was bred commercially,whereas rubber and plam oil is subject to business zakat assessment should it bred commercially. The "consensus" agricultural zakat are based on working capital and therefore the plantation costs are irrelevant for the "disensus" agricultural zakat assessment.

Based on the rules issued by JAWHAR for the "consensus" agricultural assessment, the assessment are made based on the net income or net agricultural production. In general, there are four types paddy plantation costs which are allowed to be deducted. First, the cost of fertilizers dan pesticides; second, rental cost (if any); third, labor cost and harversting cost; and forth, transportation cost which has been borne.

Nevertheless, most of the states did not use the manual issued by JAWHAR as reference. For instance, The Mufti of Selangor, after the discussion with Jawatankuasa Perunding Hukum Syara' has issued fatawa on 22nd May, 2001 ,which mentioned the zakat on paddy stood at $5 \%$ from the gross income without having to deduct the production cost or farming cost. The rationale is that the farmers need to bear high production or farming cost including water for the irrigation as well as machineries, so that they can produce good quality paddy. ${ }^{2}$

However, on 12th September, 1999, the Jemaah Ulama' Majis Agama Islam dan Adat Istiadat Melayu state of Kelantan has issued fatawa pertaining to zakat on paddy which are cultivated on project basis, as follows:-

1) Zakat are compulsory on the owners of the land who plant the paddy on big scale or on project basis based on the adequate nisâb (minimum threshold) after deducting the project management cost incurred by the implementing agencies.

2) For the purpose of coordinating and facilitating the payment of zakat, the implemnting agency can pay the zakat on behalf of the land owners after obtaining consents from the repective land owners.

On the other hand, individual farmers who plant the paddy commercially are not allowed to deduct the costs of plantations from the gross income. However, there are states such as Penang, Perlis and Sarawak which allow the deduction of the plantation costs from the gross agricultural produce.

The zakat assessment manual does not indicate the cost of living when debating about zakat assessment on

\footnotetext{
${ }^{1}$ Irrigation is the main component cost for agriculture in early Islam. Reported from Jabir that the Prophet said as follows: "The Prophet said, "On a land irrigated by rain water or by natural water channels or if the land is wet due to a nearby water channel Ushr (i.e. onetenth) is compulsory (as Zakat); and on the land irrigated by the well, half of an Ushr (i.e. one-twentieth) is compulsory (as Zakat on the yield of the land)" (al-Bukhari, Hadith No. 560).

${ }^{2}$ The Fatwa Committee State of Terengganu agreed that zakat rate of $10 \%$ " is imposed on the farmers who watered the plant using the water from the drain or trench, irrigation and such rate are imposed because the farmers need not have to suffer or work hard in getting the water and have no intention to use manpower to get the water for the plant. In the matter of tax payment paid to the government, namely "irrigation tax", the rate is not burdensome and therefore, the rate remain unchanged. In addition, the Committee confided that for rented land, the rental cost are not allowable for deduction from the agricultural income that are subject to zakat as zakat are imposed on the agriculultural income itself.
} 
paddy. In other words, this exhibits that the cost of living are not allowed to be deducted from the gross income of paddy. Therefore, this explains why most of the states in Malaysia follow the same method (Asmak Ab Rahman et. al, 2010). Nonetheless, state of Perlis allows the deduction of cost of living from the gross agricultural produce apart from the production costs. The cost of living consists of cost of living for oneself, spouse, childrens, contributions to parents and other expenses such as housing and vehicles. ${ }^{3}$

In contrast, the assessment of zakat on income allows the deduction of cost of livings from the gross income (JAKIM, 2008). The cost of living are divided into four types. First, the basic needs such as shelter, clothing, food and etc. Second, the expenses incurred for oneself, spouse, children, parents and other dependents such as siblings, adopted children, servant and etc. Third, saving account open with the institutions who pays zakat on behalf of the depositors such as Lembaga Tabung Haji, and fourth, compulsory contributions such as Employee Provident Fund, where the contributors do not have full possession on the fund until its maturity.

\section{Practices of Agricultural Zakat Assessment in Malaysia}

Based on the arguments in the Holy Quran, views from Ibn Úmar, Abu Úbayd and the practices on the assessment of zakat on income, is it fair and reasonable to deduct the cost of the plantations and cost of living from the gross income or gross agricultural production? What actions should be taken by the State Religious Council to overcome these issues?

The rules by JAWHAR mentioned that the zakat is assessed based on the net income or net agricultural production. The rates of zakat is subject to the method of irrigation used. For instance, for plants that are watered naturally with rain water, the rate is $10 \%$ and for plants which are not naturally watered, such as using manpower to fetch the water, or have to pay for the water, the rate has been fixed at 5 percent. However zakat rate of $7.5 \%$ were imposed for the plant which are watered $50 \%$ naturally and $50 \%$ with manpower.

Most of the farmers in Malaysia pay zakat based on the gross income, and the difference is only on the rate of zakat imposed. For instance, farmers in the state of Selangor pay zakat at a rate of 5 percent based on the gross income without deducting the production costs or farming cost and this was due to the fact that the farmers need to bear high plantation or farming cost including the service of watering the plant as well as the usage of the equipments, in order to get good and quality paddy. Jawatankuasa Fatwa Negeri Selangor has issued this fatawa on 22nd May, 2001.

Similarly, farmers in the state of Perak also contribute zakat at a rate of 5 percent from the gross income. This is in line with the fatawa issued by Fatwa Committee State of Perak on 2nd November 2010. In contrast, farmers in the state of Trengganu contribute zakat at a rate of $10 \%$ from the gross income. This is consistent with the fatawa issued by Fatwa Committee State of Terengganu on 2 nd June, 1990. The basis of this fatawa is that, the farmers need not have to struggle and have no intention to use manpower to get the water for the plant.

On the other hand, farmers in the state of Kelantan pay zakat at a rate of 10 percent or 5 percent depending on the source of water used, either rain water or paid water. The cost of plantation or farming are not deductible from the income. Zakat is still need to be paid eventhough the farmers suffer losses due to natural disaster such as flooded. ${ }^{4}$

Generally, for one season, the cost of planting the paddy is between RM3,000 to RM3,500 per hectare and the agricultural produce is between RM6,000 to RM7,000 per hectare. In order for the farmers to earn a profit, the output per hectare should be more than 4.5 tonnes per hectare, failing which, they will suffer losses. In assessing the zakat, the cost of production or cultivation the paddy should be deducted from the gross income, as stressed by Wan Mohd. Fadhli Wan Mamat sa follows: ${ }^{5}$

"I think the cost of plantation should be deducted based on two reasons. First, the farmers need quite a substantial amount of capital for each season. Second, the costs involved such as seeds, fertilizers and pesticides keep on increasing".

A total of 10 farmers who plant the paddy between 20 - 25 hectare were interviewed. The practices of agricultural zakat assessment among the farmers can be categorized into three. First, zakat assessment of $10 \%$ on gross income. The production cost or farming costs as well as living costs are not deducted from the gross income. It was found that

3Interview with Mohd Nazim b. Mohd Noor, General Manager of Baitulmal, State of Religious Council and Malay Customs of Perlis (MAIPs) on 27th February, 2014.

4 Interview with Dato' Muhamad Shukri b. Muhamad, Mufti of State of Kelantan on 28th July, 2013.

5 Interview with Wan Mohd. Fadhli Wan Mamat, Agriculture Engineer from Kemubu Agriculture Development Authority (KADA) on 3rd February, 2014. 
three farmers follow the zakat assessment of $10 \%$ on gross income. Second, zakat assessment of $10 \%$ on net income. The production cost or farming costs as well as living costs are deducted from the gross income. It was revealed five farmers follow this assessment. Third, the zakat assessment of $10 \%$ from the net income, excluding only the cost of production. It was noted that only two farmers follow this type of assessment.

Five farmers agreed that cost of production and cost of living should be deducted from the gross income when paying for zakat. The reason behind this was due to the fact that for paddy which is planted commercially the farmers need to bear quite substantial amount for the costs of production. Cost of living should also be deducted due to the rising cost. Mustapha Mamat mentioned as follows: 6

"The cost of plantation or farming should be deducted in paying the zakat. High plantation or farming cost need to be borne by the farmers who planted the paddy on big scale or on commercial basis. In fact, these costs keep increasing. Cost of living is the cost that should be deducted first. This was due to the rising cost of the overheads, such as bills and other daily needs."

Two farmers agreed that cost of plantation should be deducted from the gross income when paying for zakat. However, they disagree on the deduction of the cost of livings. Nor Azmi Mahmud mentioned as follows: ${ }^{7}$

"All this while, the cost of plantation are deducted in arriving at the zakat amount, because we need to bear high plantation cost. I feel that the cost of living should not be deducted because it is our responsibility to pay for our needs, which is not related to the paddy cultivation process".

Similarly, Abdul Hadi Abdul Rahman stressed that cost of living should not be deducted, as the cost of living is the responsibility of the head of family. Abdul Hadi Abdul Rahman mentioned as follows: ${ }^{8}$

"I feel the cost of living should not be deducted as it does not relates to the paddy cultivation process dan it is understood that the cost of living is our responsibility as the head of the family".

Three farmers disagree to deduct the cost of plantation and cost of living in paying the zakat. The reason being, this has been their practice with the zakat on agriculture. The rate of zakat used was $10 \%$. In detail, Masdira Hamat mentioned as follows: ${ }^{9}$

"I do not agree to deduct the cost of plantations and cost of living in paying the zakat on agriculture. This has become my habit to pay zakat on paddy based on the gross income without deducting any costs."

It has been a practice all this while not to deduct the cost of plantation and cost of living in paying the zakat. Hassan Daud argued as follows: ${ }^{10}$

"I do not agree to deduct the cost of plantations and cost of livings in paying the zakat. This is because, zakat on paddy should be paid without deducting any costs at all. We have been practicing this since the time of our parents, where zakat on paddy should be paid out of the gross income."

Majority of the Muslim scholars (Ulama) are of the opinion that the cost of plantation should be borne by the farmers, though the farmers viewed that these costs are allowed to be deducted. The scholars viewed that the cost of production should not be deducted as there was no 'nas' or 'Hadith' that stated that cost of plantation should be deducted when paying for zakat. The 'nas' or 'Hadith' only stated the rate of zakat of $5 \%$ or $10 \%$ based on the type of irrigation used (Wahbah al-Zuhaily, 1994).

On the other hand, Ibn Kathir (2001) has explained matters pertaining to the cost of living. He has put forward the opinion of Ibn Abas. Ibn Khatir (2001) further confided that Ibn Úmar, Mujahid, Ata, Ikrimah, Sa'id b. Jubayr, Muhammad b. Ka'b, Al-Hasan, Qatadah, Al-Qasim, Salim, Ata Al-Khurasani dan Ar-Rabi b. Anas shared the same view. Therefore, allowing the cost of living to be dedcuted from the paddy income serves as a strong foundation.

The above was supported with the views from Ibn Úmar who allows the expenses incurred for family. In other

\footnotetext{
6 Interview with Mustapha Mamat on 3rd January, 2014.

7 Interview with Nor Azmi Mahmud on 7th February, 2014.

${ }^{8}$ Interview with Abdul Hadi Ab. Rahman on 25th January, 2014.

9 Interview with Masdira Hamat on 8th February, 2014.

10 Interview with Hassan Daud on 11th January, 2014.
} 
words, the cost of living is dedcutible from the paddy income, let alone, the nafaqah expenses is the responsibility of the head fo the family and this nafaqah expenses should be the priority in the family before spending on other expenses. This was based on the naration by Jabir, where Prophet mentioned as follows:

"Start with yourself and grant it some charity. If anything remains, then spend it on your family. If anything remains, then spend it on your relatives. If anything remains, then spend it like this and like that (i.e., on various charitable purposes)" (Ibn Kathir, 2001: 153).

The actual needs of the cost of living is subject to the current situation. In other words, the amount of the cost of living must be determine by qualified personal, with the consent by the government.

Abu Ubayd mentioned that Ibn Úmar if of the opinion that the cost of paddy plantation is allowable for deduction and the same view were shared by Ibn Abbas. In fact, Úmar Ibn Abd. Aziz has written a letter to the Govenor of Palastin, Abdullah Ibn Auf to collect the amount of zakat by deducting the kharaj tax.

The comment from Abu Ubayd seems to be very interesting where Prophet described that zakat are taken from the rich and distributed to the poor. Therefore, it is not possible for someone who is indebted and does not possessed any porperty to become the zakat payer and also it is not possible for someone who may be rich as well as poor at the same time. In fact, the indebted person is actually the recipients (asnaf) of zakat.

As such, Yusuf al-Qardawi (1999) argued that cost of plantation should be first deducted as it caused burden to the farmers. He further confided that burden and cost are the factors that influences the determination of the law (hukum). For instance, the irrigation method used influences the determination of the rate for zakat on argiculture. The rate on zakat varies due to the factors of burden and cost. For example, for the irrigation method that used equipments or manpower, the zakat rate has been fixed at $5 \%$.

In the state of Perlis, the practice of zakat on agriculture allows the cost of plantation as well as cost of living to be deducted from the agrculture income and other states' religious council should review the practice by state of Perlis and should follow suit. This suggestions was based on the sources from the Holy Quran, view from Ibn Úmar, Hadith from Jabir and the practices of the assessment of zakat on income. The State Islamic Religious Councils in Malaysia should have realized and be aware of this issues.

\section{Conclusion}

Two conclusions can be derived from the above discussion. First, based on the argument from the Holy Quran, views from Ibn Úmar, Abu Úbayd and the practices of the assessment of zakat on income in Malaysia,it is fair and resasonable to allow the deduction of the cost of plantation and cost of living from the gross income of paddy.

Second, apart from the above, the assessment of zakat on agricultural income should allow the deduction of plantation cost as nowadays most of the agricuture project are done commercially. The impact of not allowing the deduction of these costs might affect the transformation of the farmers from being zakat receiver to zakat payer, especially during the hardship such as natural disaster.

\section{Acknowledgement}

The author would like to express his appreciation to the Universiti Sains Malaysia (USM) for the funding of this research through Research University Grants (1001/PSOSIAL/816218).

\section{References}

Abu Abu Úbayd al-Qasim b. Salam. (2006). Kitab al-Amwal. (Noor Mohammad Ghiffari, Trans.). Islamabad: Pakistan Hijra Council.

Asmak Ab Rahman, Pazim@Fadzim Othman, Siti Mashitoh Mahamood, Nor Aini Ali \& Azizi Che Seman. (2010). Assessment Method for Agricultural Zakat in Malaysia: An Institutional Perspective. World Applied Sciences Journal 11(12):1500-1508.

Ibn Kathir. (2001). Tafsir Ibn Kathir. Riyadh: Darussalam.

Jabatan Wakaf, Zakat dan Haji (JAWHAR). (2008). Manual Pengurusan Pengiraan Zakat. Putrajaya: Jabatan Wakaf, Zakat dan Haji.

Wahbah al-Zuhaily. (1994). Fiqh \& Perundangan Islam. (Md. Khir Hj. Yaacob et al., Trans.). Jld. III. Kuala Lumpur: 
Dewan Bahasa dan Pustaka.

Yusuf al-Qaradawi. (1999). Fiqh az-Zakat: A Comparative Study. (Monzer Kahf, Trans.). London: Dar Al Taqwa Ltd. 